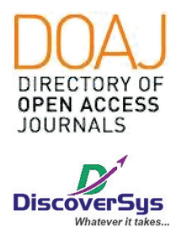

Published by DiscoverSys

\title{
Gambaran pola makan, kecukupan gizi, dan status gizi mahasiswa Fakultas Kedokteran Universitas Mataram, Nusa Tenggara Barat
}

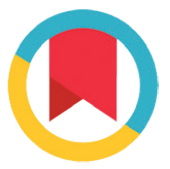

CrossMark

\author{
Rifana Cholidah, ${ }^{*}$ Ida Ayu Eka Widiastuti, Lina Nurbaiti, Seto Priyambodo
}

\section{ABSTRACT}

Background: Nutritional problem is a problem that still faced by developed countries and developing countries. An unbalanced diet is one of the causes of nutritional problems. Several studies have shown that students have an unhealthy diet and eating habits. Several factors influences such as high academic activity, limited food choices around the campus, and choosing food at affordable prices. This study aims to determine the eating pattern, nutrition adequacy, and nutritional status of the students in the Medical Faculty of Universitas Mataram, Mataram, West Nusa Tenggara, Indonesia.

Methods: This descriptive-analytical study involving students of the Medical Faculty of Universitas Mataram who met the inclusion and exclusion criteria as subjects. Subjects were obtained using a consecutive sampling method. Measurement of dietary and nutritional adequacy using a 24-hours food recall questionnaire and NutriSurvey software, and calculation of nutritional status based on body mass index (BMI).

Results: A total of 88 students were included in this study. Students with proper and improper diet pattern were 38 (43.18\%) and 50 (56.82\%). Students with sufficient nutrition were 42 (47.73\%), and 46 (52.27\%) were lack of adequate nutrition. Based on the nutritional status, 18 (20.45\%) were underweight, 58 (65.91\%) were normal, $8(9.09 \%)$ were overweight, and 4 (4.54\%) were obesity.

Conclusion: Most students have improper eating patterns, lack of adequate nutrition, and normal nutritional status.
Fakultas Kedokteran Universitas Mataram

*Korespondensi: Rifana Cholidah, Fakultas Kedokteran Universitas Mataram rifana.cholidah@gmail.com

Keywords: Eating pattern, nutritional adequacy, nutritional status, medical students Cite This Article: Cholidah, R., Widiastuti, I.A.E., Nurbaiti, L., Priyambodo, S. 2020. Gambaran pola makan, kecukupan gizi, dan status gizi mahasiswa Fakultas Kedokteran Universitas Mataram, Nusa Tenggara Barat. Intisari Sains Medis 11(2): 416-420. D0I: 10.15562/ism.v11i2.589

\section{ABSTRAK}

Latar belakang: Masalah gizi berupa kekurangan dan kelebihan gizi masih menjadi masalah baik di negara berkembang maupun negara maju. Masalah gizi ini dapat disebabkan adanya pola makan yang tidak seimbang. Beberapa penelitian menunjukkan bahwa mahasiswa memiliki pola makan dan kebiasaan makan yang tidak sehat, karena pengaruh beberapa faktor seperti kesibukan akademik, pilihan makanan yang terbatas di sekitar kampus, dan memilih makanan dengan harga yang terjangkau. Penelitian ini bertujuan untuk mengetahui gambaran pola makan, kecukupan gizi, dan status gizi mahasiswa Fakultas Kedokteran Universitas Mataram, Nusa Tenggara Barat

Metode: Penelitian ini adalah penelitian analitik deskriptif dengan desain potong-lintang. Subjek penelitian adalah mahasiswa Fakultas Kedokteran Universitas Mataram yang memenuhi kriteria inklusi dan eksklusi. Subjek penelitian diperoleh dengan menggunakan metode consecutive sampling. Pada subjek dilakukan analisis pola makan dan kecukupan gizi menggunakan kuisioner 24-hour food recall dan software NutriSurvey, serta perhitungan status gizi berdasarkan indeks massa tubuh (IMT).

Hasil: Sebanyak 88 mahasiswa diikutsertakan dalam penelitian ini. Terdapat 38 mahasiswa $(43,18 \%)$ dengan pola makan yang benar dan 50 mahasiswa (56,82\%) dengan pola makan yang salah. Terdapat 42 mahasiswa (47,73\%) cukup gizi dan 46 mahasiwa (52.27\%) berada pada angka kecukupan gizi kurang. Untuk status gizi, 18 mahasiswa (20,45\%) dengan status gizi kurang, 58 mahasiswa $(65,91 \%)$ dengan status gizi normal, 8 mahasiswa $(9,09 \%)$ dengan status gizi berat badan lebih, dan 4 mahasiswa (4,54\%) dengan status gizi obesitas.

Simpulan: Pola makan mahasiswa sebagian besar masih kurang tepat, angka kecukupan gizi sebagian besar kurang. Sebagian besar mahasiswa mempunyai status gizi normal.

Kata kunci: pola makan, kecukupan gizi, status gizi, mahasiswa kedokteran

Cite Pasal Ini: Cholidah, R., Widiastuti, I.A.E., Nurbaiti, L., Priyambodo, S. 2020. Gambaran pola makan, kecukupan gizi, dan status gizi mahasiswa Fakultas Kedokteran Universitas Mataram, Nusa Tenggara Barat. Intisari Sains Medis 11(2): 416-420. D0I: 10.15562/ism.v11i2.589

\section{PENDAHULUAN}

Masalah gizi berupa kekurangan dan kelebihan gizi masih menjadi masalah baik di negara berkembang maupun negara maju. Secara nasional, berdasarkan hasil Riset Kesehatan Dasar (Riskesdas) tahun 2013, 
terdapat 9,4\% remaja usia 16-18 tahun mempunyai status gizi kurus, 5,7\% gemuk dan 1,6\% obesitas. ${ }^{1}$ Pada negara maju seperti Amerika Serikat, sekitar 16\% dari remaja berusia 6-19 tahun termasuk dalam kategori gemuk. ${ }^{2}$ Faktor gizi mempunyai peranan yang sangat penting dalam mengembangkan potensi sumber daya manusia dan kualitas hidup yang lebih baik dengan harapan hidup yang lebih panjang. Pola makan yang sehat akan memberikan kombinasi energi dan nutrisi yang tepat bagi tubuh. Pola makan tersebut harus memenuhi keempat kriteria berikut: adekuat, moderat, seimbang dan bervariasi. ${ }^{2,3,4}$

Asupan makanan yang adekuat akan dapat menyediakan energi, nutrisi, dan serat yang cukup untuk dapat memelihara kesehatan tubuh. Asupan makanan biasanya tidak adekuat hanya pada satu kelompok makanan. Seperti di Amerika Serikat, sebagian besar dari populasinya kurang mengkonsumsi sayur-sayuran, sehingga menyebabkan konsumsi nutrisi yang ada didalam sayur-sayuran seperti serat, vitamin C, beta karoten dan potassium juga tidak adekuat. Malnutrisi dapat terjadi pada individu dengan konsumsi makanan dan nutrisi yang tidak adekuat dalam waktu yang lama. Sebagai contoh, makin banyaknya remaja putri dan mahasiswi universitas yang mengikuti pola makan yang ketat untuk mempertahankan tubuh agar tetap kurus. Mereka biasanya melewatkan satu atau lebih waktu makan setiap hari, tidak makan makanan yang berlemak dan membatasi jenis makanan yang mereka konsumsi seperti roti, pisang dan salad. Jenis pola makan restriktif tersebut apabila dijalani dalam jangka waktu yang lama dapat mengakibatkan rendahnya cadangan energi, kerapuhan tulang, kerontokan rambut, berkurangnya daya ingat dan fungsi kognitif dan gangguan menstruasi. ${ }^{2,5}$

Mahasiswa, terutama mahasiswa kedokteran mewakili golongan yang berbeda dari kelompok masyarakat pada umumnya terkait dengan gizi, hal ini disebabkan mereka memiliki pengetahuan yang relatif lebih tinggi mengenai pola makan dan gizi. ${ }^{6}$ Penelitian Pola makan dan status gizi yang dilakukan terhadap 47 mahasiswa Fakultas Kedoteran pada tahap kuliah klinik senior (KKS) bagian Obgyn RSUD dr. Zainoel Abidin Banda Aceh melaporkan sebanyak 27 mahasiswa (57,45\%) dengan pola makan yang benar, dan 20 mahasiswa $(42,55 \%)$ dengan pola makan yang salah. ${ }^{7}$ Penelitian ini bertujuan untuk mengetahui gambaran pola makan, kecukupan gizi, dan status gizi mahasiswa Fakultas Kedokteran Universitas Mataram, Nusa Tenggara Barat.

\section{METODE}

Penelitian ini merupakan penelitian survei analitik deskriptif dengan desain potong-lintang pada bulan April sampai dengan Desember 2017. Pola makan, kecukupan gizi dan status gizi diukur secara simultan. Pola makan diukur berdasarkan asupan makanan pada zat gizi makro, yaitu: karbohirat, lemak, dan protein. Subjek penelitian adalah mahasiwa tahun pertama semester II Fakultas Kedokteran Universitas Mataram, yang memenuhi kriteria inklusi dan diperoleh dengan menggunakan metode consecutive sampling. Subjek mengisi kuesioner 24-hour food recall untuk menghitung asupan makanan hari tersebut, selanjutnya data dianalisis dengan menggunakan Software NutriSurvey. Hasil analisis NutriSurvey dibandingkan dengan komposisi makronutrien yang memenuhi kriteria WHO yaitu asupan makanan yang berasal dari karbohidrat $=55-75 \%$, total lemak $=15-30 \%$, Protein $=10-15 \%$ untuk menilai pola makan. Hasil analisis NutriSurvey dibandingkan dengan angka kecukupan gizi (AKG) 2013 untuk menilai angka kecukupan gizi. Status gizi responden pada penelitian ini dinilai berdasarkan hasil pengukuran indeks massa tubuh (IMT) dibandingkan dengan kriteria status gizi yang dikeluarkan oleh Kementrian Kesehatan yang tertuang dalam Riskesdas 2013 untuk usia $\geq 18$ tahun. Analisis data secara deskriptif dan analitik dilakukan dengan menggunakan SPSS.

\section{HASIL}

\section{Karakteristik Responden}

Subjek penelitian yang termasuk dalam penelitian ini adalah 88 mahasiswa. Seluruh subjek penelitian dapat mengikuti penelitian ini sampai selesai dan tidak ada subjek penelitian yang dieksekusi. Karakteristik dan data antropometri responden pada penelitian ini tertuang pada Tabel 1 .

Mahasiswa pada penelitian ini rata-rata berusia 19 tahun. Dari 88 orang mahasiswa yang berpartisipasi dalam penelitian ini responden laki-laki berjumlah 26 orang $(29,5 \%)$ dan responden perempuan berjumlah 62 (70,5\%). Rerata tinggi badan $160 \mathrm{~cm}$, rerata berat badan $53,88 \mathrm{~kg}$ dan rerata indeks masa tubuh (IMT) 21,05 kg/m².

\section{Pola Makan}

Pola makan mahasiswa pada masing-masing zat gizi di kategorikan menjadi dua: yaitu pola makan benar (sesuai dari kriteria WHO) dan pola makan salah (kurang dari atau melebihi kriteria WHO). Adapun gambaran pola makan pada penelitian ini tertuang pada Tabel 2.

Berdasarkan analisis pola makan mahasiswa pada penelitian didapatkan sejumlah 49 orang (55,68\%) mempunyai pola makan dengan komposisi kurang asupan karbohidrat, 39 orang (44,32\%) cukup atau memenuhi kriteria WHO dan tidak ada 
Tabel 1 Karakteristik Responden

\begin{tabular}{lcc}
\hline Karakteristik & $\mathbf{N}$ & $\%$ \\
\hline Usia & & \\
$\quad$ Rerata (tahun) & 19,0 & \\
Jenis kelamin & & 29,5 \\
$\quad$ Laki-laki & 26 & 70,5 \\
$\quad$ Perempuan & 62 & \\
Tinggi badan & & \\
$\quad$ Rerata (cm) & 160 & \\
Berat badan & & \\
$\quad$ Rerata $(\mathrm{kg})$ & 53,8 & \\
Indeks massa tubuh & & \\
$\quad$ Rerata $\left(\mathrm{kg} / \mathrm{m}^{2}\right)$ & 21,0 & \\
\hline
\end{tabular}

Tabel 2 Gambaran Pola Makan

\begin{tabular}{lcccccc}
\hline & \multicolumn{3}{c}{ Asupan makanan } & & \multicolumn{2}{c}{ Pola makan } \\
\cline { 2 - 3 } \cline { 7 - 7 } Makronutrien & $\begin{array}{c}\text { Kurang } \\
\text { N (\%) }\end{array}$ & $\begin{array}{c}\text { Cukup } \\
\text { N (\%) }\end{array}$ & $\begin{array}{c}\text { Lebih } \\
\text { N (\%) }\end{array}$ & & $\begin{array}{c}\text { Benar } \\
\text { N (\%) }\end{array}$ & $\begin{array}{c}\text { Salah } \\
\text { N (\%) }\end{array}$ \\
\hline Karbohidrat & $49(55,68)$ & $39(44,32)$ & $0(0)$ & & $39(44,32)$ & $49(55,68)$ \\
Protein & $5(5,68)$ & $33(37,50)$ & $50(56,82)$ & $33(37,5)$ & $55(62,5)$ \\
Lemak & $0(0)$ & $43(48,86)$ & $45(51,14)$ & $43(48,86)$ & $45(51,14)$ \\
Rerata & & & & $38(43,18)$ & $50(56,82)$ \\
\hline
\end{tabular}

Tabel 3 Tingkat Kecukupan Zat Gizi Makro

\begin{tabular}{lccccc}
\hline & \multicolumn{5}{c}{ Angka kecukupan gizi } \\
\cline { 2 - 3 } \cline { 5 - 6 } Makronutrien & N & Cukup & & \multicolumn{2}{c}{ Kurang } \\
\cline { 2 - 3 } \cline { 5 - 6 } Karbohidrat & 35 & 39,77 & & 53 & N \\
Protein & 43 & 48,86 & & 45 & 50,23 \\
Lemak & 49 & 55,68 & & 39 & 44,32 \\
Rerata & 42 & 47,73 & & 46 & 52,27 \\
\hline
\end{tabular}

\section{Tabel 4 Gambaran Status Gizi}

\begin{tabular}{lcc}
\hline Status Gizi & N & $\%$ \\
\hline Kurus & 18 & 20,45 \\
Normal & 58 & 65,91 \\
BB lebih & 8 & 9,09 \\
Obesitas & 4 & 4,54 \\
\hline
\end{tabular}

responden yang mengkonsumsi karbohidrat secara berlebih. Berdasarkan asupan karbohidrat, didapatkan sebanyak 39 mahasiswa $(44,32 \%)$ mempunyai pola makan yang benar dan 49 orang $(55,68 \%)$ mempunyai pola makan yang salah.

Berdasarkan asupan protein didapatkan sejumlah 5 orang $(5,68 \%)$ mempunyai pola makan dengan komposisi kurang asupan protein, 33 orang $(37,50 \%)$ cukup atau memenuhi kriteria WHO, dan 50 orang $(56,82 \%)$ mengkonsumsi protein secara berlebih. Berdasarkan asupan protein, didapatkan sebanyak 33 mahasiswa $(37,50 \%)$ mempunyai pola makan yang benar dan 55 orang $(62,5 \%)$ mempunyai pola makan yang salah.

Berdasarkan asupan lemak tidak didapatkan mahasiswa yang kurang asupan lemak dalam komposisi diet mereka sehari-hari, 43 orang $(48,86 \%)$ cukup atau memenuhi kriteria WHO, dan didapatkan sebanyak 45 orang $(51,14 \%)$ mengkonsumsi lemak secara berlebih. Apabila dilihat dari pola makan, didapatkan sebanyak 43 mahasiswa $(48,86 \%)$ mempunyai pola makan yang benar dan 45 orang $(51,14 \%)$ mempunyai pola makan yang salah. Secara keseluruhan terdapat 38 mahasiswa $(43,18 \%)$ dengan pola makan yang benar dan 50 mahasiswa $(56,82 \%)$ dengan pola makan yang salah.

\section{Kecukupan Gizi}

Kriteria kecukupan zat gizi makro yaitu: karbohidrat, lemak dan protein dibedakan menjadi dua kategori, yaitu: kurang $(<80 \%$ AKG) dan cukup ( $\geq 80 \%$ AKG). Tabel 3 menggambarkan tingkat kecukupan zat gizi makro.

Berdasarkan asupan karbohidrat, sebanyak 35 orang mahasiswa $(39,77 \%)$ mempunyai tingkat kecukupan gizi yang sesuai dan 53 orang $(60,23 \%)$ berada pada tingkat kecukupan gizi yang kurang. Sementara itu, 43 orang mahasiswa $(48,86 \%)$ memehuni kecukupan gizi pada asupan protein dan 45 orang $(51,14 \%)$ mahasiswa berada pada tingkat kecukupan zat gizi protein yang kurang. Berdasarkan asupan lemak, sebanyak 49 mahasiswa $(55,68 \%)$ berada pada tingkat kecukupan gizi yang cukup, angka ini lebih besar dibandingkan dengan angka kecukupan gizi karbohidrat dan protein. Sebanyak 39 mahasiswa (44,32\%) mempunyai angka kecukupan gizi kurang untuk asupan lemak. Secara keseluruhan, 42 mahasiswa $(47,73 \%)$ cukup gizi dan 46 mahasiwa $(52,27 \%)$ berada pada angka kecukupan gizi kurang.

\section{Status Gizi}

Status gizi dikategorikan menjadi empat kategori, yaitu: kurus (IMT $<18,5$ ), normal (IMT $\geq 18,5-$ $<24,9)$, berat badan (BB) lebih $(\geq 25,0-<27,0)$ dan obesitas IMT $\geq 27,0$. Adapun gambaran status gizi mahasiswa pada penelitian ini tertuang pada Tabel 4. Mahasiswa dengan status gizi kurang berjumlah 18 orang (20,45\%), mahasiswa dengan status gizi normal berjumlah 58 orang $(65,91 \%)$, mahasiswa dengan status gizi berat badan (BB) lebih (overweight) berjumlah 8 orang $(9,09 \%)$ dan 
mahasiswa dengan status gizi obesitas berjumlah 4 orang $(4,54 \%)$.

\section{PEMBAHASAN}

Pola makan menggambarkan cara individu dalam memilih dan mengonsumsi jenis makanan yang diinginkan sebagai reaksi dari kebutuhan fisiologis, psikologis, sosial, dan budaya. Hal ini dipengaruhi oleh beberapa faktor, seperti pendapatan, pekerjaan, pendidikan, tempat tinggal (desa atau kota), agama dan kepercayaan, pengetahuan gizi, dan karakteristik fisiologis. ${ }^{10,11}$ Berdasarkan analisis pola makan pada penelitian ini, terdapat 38 mahasiswa $(43,18 \%)$ dengan pola makan yang benar dan 50 orang mahasiswa (56,82\%) dengan pola makan salah. Penelitian oleh Thomson memaparkan bahwa makin banyak remaja putri dan mahasiswi universitas yang mengikuti pola makan yang ketat untuk mempertahankan tubuh agar tetap kurus. Mereka biasanya melewatkan satu atau lebih waktu makan setiap hari, tidak makan makanan yang berlemak, dan membatasi jenis makanan yang mereka konsumsi seperti roti, pisang, dan salad. ${ }^{2}$ Sementara itu penelitian yang dilakukan oleh Husnah (2012) terhadap 47 mahasiswa Fakultas Kedokteran pada tahap kuliah klinik senior (KKS) bagian Obgyn RSUD dr. Zainoel Abidin Banda Aceh mendapatkan sebanyak 27 mahasiswa (57,45\%) dengan pola makan yang benar, dan 20 mahasiswa (42,55\%) dengan pola makan yang salah. ${ }^{7}$ Persentase mahasiswa dengan pola makan yang benar pada penelitian ini lebih rendah dibandingkan dengan yang dilaporkan oleh Husnah (2012), hal ini dapat disebabkan karena subyek penelitian ini adalah mahasiswa tahun pertama semester II dengan pengetahuan mengenai pola makan dan gizi relatif lebih rendah dibandingkan dengan mahasiswa fakultas kedokteran pada tahap kuliah klinik senior. ${ }^{7}$ Pada penelitian ini, dari 88 partisipan, didapatkan 18 mahasiswa (20,45\%) dengan status gizi kurang, 58 mahasiswa $(65,91 \%)$ dengan status gizi normal, 8 mahasiswa $(9,09 \%)$ dengan status gizi berat badan lebih (overweight) dan 4 mahasiswa $(4,54 \%)$ dengan status gizi obesitas. Pada penelitian serupa yang dilakukan oleh Ruslie \& Darmadi (2012) terhadap mahasiswa Fakultas Kedokteran Atma Jaya Jakarta, dari 144 mahasiswa yang menyelesaikan penelitian, didapatkan prevalensi underweight 9,03\%, status gizi normal 70,83\%, dan overweight $20,14 \% .^{12}$

Status gizi individu menggambarkan nutrisi yang dikonsumsi dalam keseharian. Status gizi yang baik didapatkan dari pola makan seimbang. Bila asupan makanan melebihi kebutuhan tubuh maka tubuh akan kelebihan berat badan bahkan kegemukan. sebaliknya apabila asupan makanan kurang dari kebutuhan, tubuh akan kurus dan dapat terserang beberapa penyakit. ${ }^{2,7}$

\section{SIMPULAN}

Persentase mahasiswa yang mempunyai gizi normal di Fakultas Kedokteran Universitas Mataram dan mahasiswa Fakultas Kedokteran Universitas Atma Jaya Jakarta relatif sama. Sementara itu, mahasiswa pada penelitian ini mempunyai persentase gizi kurang (underweight) lebih tinggi dan persentase gizi berat badan lebih (overweight) lebih rendah dibandingkan dengan mahasiswa Fakultas Kedokteran Atma Jaya Jakarta.

\section{PERSETUJUAN ETIK}

Penelitian ini mendapatkan persejuan etik dari Komite Etik Fakultas Kedokteran Universitas Mataram.

\section{KONFLIK KEPENTINGAN}

Penulis menyatakan tidak terdapat konflik kepentingan terkait penelitian ini.

\section{PENDANAAN}

Penelitian ini dibiayai dari sumber dana DIPA BLU (PNBP) Universitas Mataram tahun anggaran 2017.

\section{KONTRIBUSI PENULIS}

Seluruh penulis terlibat dalam penelitian dimulai dengan peyusunan proposal penelitian hingga publikasi hasil penelitian.

\section{DAFTAR PUSTAKA}

1. Departemen Kesehatan. Riset Kesehatan dasar 2013. Jakarta: Departemen Kesehatan Republik Indonesia. 2013.

2. Thompson JL, Manore MM, Vaughan L. The Science of Nutrition: What disorders can result from inadequate intakes of nutrients involved in blood health?. Benjamin Cummings. 2011.

3. Almatsier S. Prinsip Dasar Ilmu Gizi. Jakarta: Gramedia Pustaka Utama. 2010.

4. Sediaoetama. Ilmu gizi untuk mahasiswa dan profesi. Jakarta: Dian Rakyat. 2010.

5. Deshpande S, Basil MD, Basil, DZ. Factors influencing healthy eating among college students: an application of the health belief model. Health marketing Quartery. 2009; 26: $145-164$

6. Stefanikova Z, et al. Positif and negatif trends in university students food intake. Bratisl Lek Listy. 2006; 107 (5): 217-220.

7. Husnah. Gambaran pola makan dan status gizi mahasiswa kuliah klinik senior (KKS) di Bagian Obsgyn RSUD dr. Zainoel Abidin Banda Aceh. Jurnal Kedokteran Syiah Kuala. 2012; 12(1): 23-30. 
8. Dahlan MS. Statistik untuk kedokteran dan kesehatan. Edisi kelima. Salemba Medika: Jakarta. 2011.

9. Amelia S. Permenkes Tentang Angka Kecukupan Gizi. 2014. Diakses pada: 12 April 2019 Situs: http://gizi.depkes. go.id/permenkes-tentang-angka-kecukupan-gizi

10. Suci SP. Faktor-faktor yang berhubungan dengan pola makan Mahasiswa Kesehatan Masyarakat Fakultas Kedokteran dan Ilmu Kesehatan Universitas Islam Negeri Syarif Hidayatullah Jakarta tahun 2011 [Skripsi]. Jakarta: Universitas Islam Negeri Syarif Hidayatullah. 2014.

11. Dewi IGAMS, Seriani L. Gambaran status nutrisi, pola konsumsi sarapan dan cemilan pada siswa Sekolah Dasar Negeri 1 Gianyar. Intisari Sains Medis. 2015; 3(1): 76-82.
12. Ruslie RH, Darmadi. Analisis regresi logistik untuk faktor-faktor yang mempengaruhi status gizi remaja. Majalah Kedokteran Andalas. 2012;36(1).

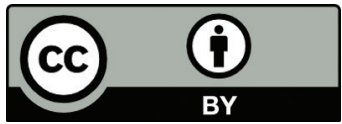

This work is licensed under a Creative Commons Attribution 